\title{
The environmental situation of the ash medical waste in Baghdad city, Iraq
}

\author{
Sari Jaber ${ }^{1}$, Alaa Aldin Aljawad ${ }^{1}$, Tudor Prisecaru ${ }^{1}$ and Elena Pop ${ }^{1, *}$ \\ ${ }^{1}$ University Politehnica of Bucharest, Faculty of Mechanical Engineering and Mechatronics
}

\begin{abstract}
The paper presents and discusses medical waste issues (including the hazardous ones 15\%) and their proper management in Iraq. Hence, improper handling of infectious medical waste endangers human health and the environment. Incineration is considered one of the effective ways to dispose of medical waste, especially in the time of Coronavirus (COVID-19) can eliminate all pathogens, reduce waste weight by more than $60-75 \%$ by weight and reduce volume accordingly. But that goes with 9 a large quantities of heavy metals and reactive, toxic materials produced, which are throws in municipal in the landfill area. That causes pollution of the soil, groundwater and air as a result of its light flying ash. The only disposal method available in Iraq is incineration in purpose-built incinerators. This paper examined three incineration processes for three hospitals in Bagdad; Medical City Complex, Al-Amal National Hospital and Al Shifa coronavirus Hospital, and we worked on burning waste and analyzing ash. The results were that most of the waste after incineration had high heavy mineral concentrations and a small amount of other materials.
\end{abstract}

\section{Introduction}

Medical waste can define as any solid wastes generated in the diagnosis, treatment or immunization of human beings or animals, research about it, or the production or testing of biological [1]. Because of increasing quantities and inadequate management system, medical waste management and selection of appropriate management systems are also important global problems worldwide. Incineration and disposal of the resultant, such as ash, could be determined as a proper application for managing medical waste. However, it is possible to obtain a $70 \%$ mass and $90 \%$ volume reduction in medical waste using the incineration process [2]. Considerable amounts of solid residuals, such as bottom and fly ashes containing heavy metals, are produced during this process [3, 4]. Furthermore, medical waste defined as any solid waste generated in the diagnosis, treatment or immunization of human beings or animals in related research, biological production or testing. The hazards to human health and the environment posed by medical waste justify a high level of concern with its management. Medical waste classified according to its source, typology and risk factors associated with handling, storage and ultimate disposal. Treatment by incineration and disposal of the resultant ash by landfilling is the most widely

\footnotetext{
* Corresponding author: elena.pop@upb.ro
} 
used treatment process for managing medical waste. A properly operated incinerator reduces the waste volume by about $90 \%$, decreasing final residues to a relatively small amount.

Suppose correct practices of main tenancy and operation used during the incineration process. In that case, ashes can be innocuous, being possible to landfill them $[5,6]$. According to the World Health Organization (WHO), $80 \mathrm{wt} \%$ of the waste generated at health units present similar properties with the corresponding of municipal solid wastes. The remaining $20 \%$ has been classified as hazardous, appearing properties such as infectivity, toxicity, carcinogenicity, radioactivity, thus requiring special treatment $[7,8]$. This typically contains many kinds of potentially infectious and toxic materials [9]. Medical waste that is not properly handled and disposed of represents a high risk of infection or injury to healthcare personnel and lesser risk to the general public through the spread of micro-organisms from healthcare facilities into the environment [10]. Medical waste is mainly composed of $26.69 \%$ organic garbage, $25.10 \%$ paper, $35.29 \%$ medical plastic waste, $8.13 \%$ glass, $0.44 \%$ metal, $1.19 \%$ textile fibre, and $3.17 \%$ wood timber [11], which has characteristics of high energy-dense and high volatiles since it contains a high proportion of organic matters [12], and found that the evolved volatile products from medical waste pyrolysis included 2-butanone, benzaldehyde, formic acid, acetic acid, hydrocarbon, carbon dioxide, carbon monoxide, and water [8, 11].

Baghdad, Iraq capital, the yearly amount of medical waste-collecting form 294 health institutions is approximately 1902 tons. Medical wastes collected separately from health institutions transported with special vehicles to medical waste site incineration located in said or outside the hospital. The capacity of the incineration is different depending on the number of beds. Some have a one or two-stage combustion system consisting or a rotary kiln or a secondary combustion chamber; at a temperature between 400 and $1000^{\circ} \mathrm{C}$, the ash transferred to landfill sites. Volume and mass reductions of incineration facility are $95 \%$ and $75 \%$, respectively [3].

\section{Waste characteristics suitable for burning}

According to the specifications of the World Health Organization (WHO):

- The waste treated by burning must have a calorific value of no less than $14650 \mathrm{~kJ} / \mathrm{kg}$;

- The proportion of combustible materials is more than $60 \%$;

- The percentage of non-combustible materials is less than $5 \%$;

- The moisture content is less than $30 \%$.

As for the waste not suitable for burning, it represented by the following:

- Compressed gas containers;

- Imaging waste (silver salts) and radiography;

- Plastic waste as a PVC material;

- Large quantities of active chemical waste;

- Closed ampoules or ampoules containing heavy elements;

- Waste containing large amounts of mercury and cadmium, such as a broken thermometer and used batteries.

\subsection{The factors that enhance the efficiency of the burning process}

The efficiency of the burning process lies in the occurrence of a case of complete combustion of waste, that is, the conversion of organic materials in the incinerator to neutral gases such as carbon dioxide gas, water vapour, sulphur oxides and nitrogen, and the factors that join this case: 
- The characteristics of the burned waste and the feed rate of the incinerator, as the presence of large quantities of plastic, prevents the completion of the burning process well, as this material, when exposed to high temperatures, softens and kneads and surrounds the rest of the waste, preventing it from burning completely, in addition to that burning the plastic and the presence of the resulting water vapour generates. One of the main causes of emission of dioxin is hydrochloric acid, which causes erosion of the liner of the incinerator over time, the burning of plastics, especially polyethylene vinyl chloride (PVC).

- Moisture content: the higher the moisture content, the more time the burning process needs.

- Temperatures: the temperatures must be in a manner that ensures the combustion process's completion. For medical waste, the temperatures at which the combustion process takes place ranges between $(900-1200)^{\circ} \mathrm{C}$.

- The presence of a mechanism for turning the waste inside the incinerator (Baffles), where the burning efficiency increases with the degree of stirring to ensure that it exposed to oxygen in quantity sufficient to complete the burning.

\subsection{Waste incineration products}

The waste incineration products, in general, can be divided into two main parts:

- Emission and releases to the external environment or the atmosphere, which include multiple gases and volatile particles, and these gases, are usually carbon oxides, sulphur oxides, chlorides and fumes of organic compounds of halogens or hydrocarbons in addition to dioxins and furans whose concentration increases, with an increase in the percentage of burnt plastic, especially PVC. The volatile includes fly ash, which forms a percentage of the total ash content. It contains a percentage of heavy elements in its standard form or its salts (zinc, cadmium, nickel, lead, mercury, manganese, etc.);

- Ash left in the incineration chamber (bottom ash), and some materials are not combustible. The ash left inside the combustion chamber constitutes (75-90\%) of the total ash generated from the burning process. It contains a percentage of the aforementioned heavy metals, which makes the ash of hazardous waste due to the effect of its high toxicity on the groundwater if it disposed of by burying it in the soil without pre-treatment, such as placing it in special containers before burying it and preparing the site correctly.

\subsection{Bottom and fly ashes characterization}

There are two types of ashes produced from medical waste burning:

- The fly ash derived from the incinerator waste gases de-dusting system (fabric filter dust collector);

- The bottom ash produced from the heavier particles of the agglomerated remaining matter precipitated and accumulated usually in the combustion chamber.

The coarser bottom ash appeared black, opaque and glassy, while the finer fly ash, grey in colour (figure 1). 


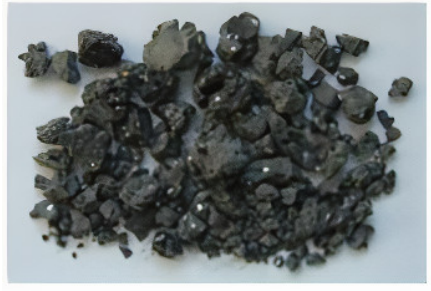

Bottom ath

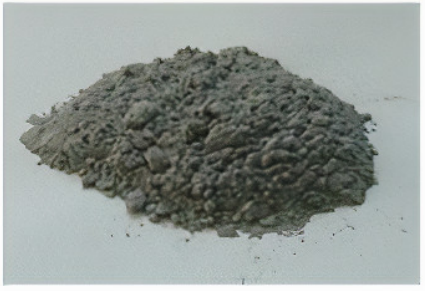

Fly alh

Fig. 1. Incineration ashes, produced during the combustion of medical wastes [2]

Most heavy metals migrate or concentrate in the fly ash and bottom ash depending on the compounds of heavy metals and their physicochemical properties during incineration. The migration of heavy metals during incineration is showing in figure 2 .
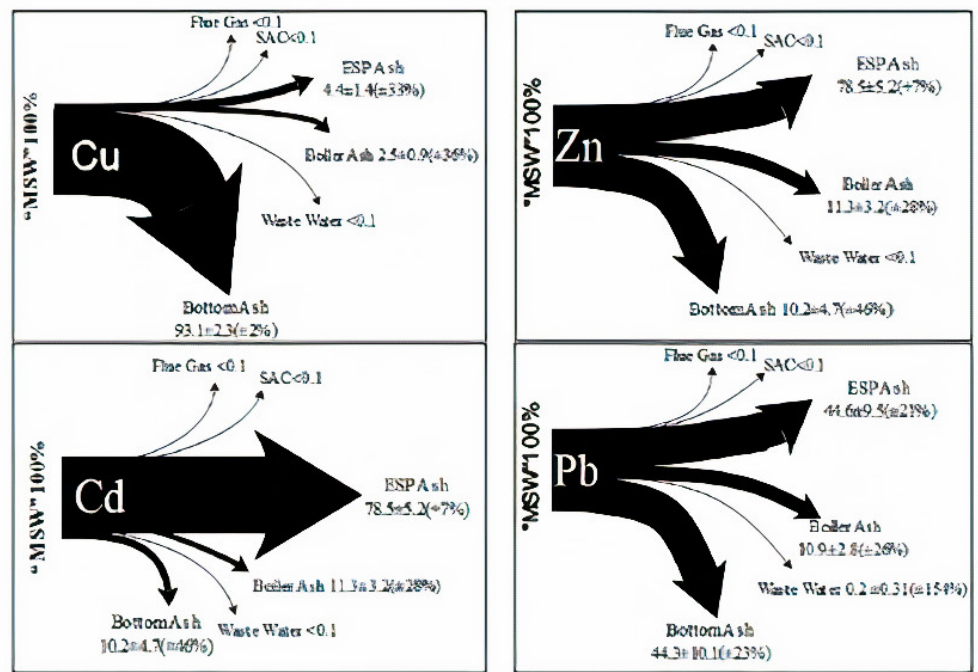

Fig. 2. Partitioning of $\mathrm{Cu}, \mathrm{Zn}, \mathrm{Cd}$, and $\mathrm{Pb}$ during medical waste incineration [13]

\section{The study \& experiments}

\subsection{Area of study}

The medical services sector is responsible for providing health care to the citizen through the services it provides in diagnosis, examination and treatment. This important vital sector includes health institutions such as government and private hospitals, health centres, health laboratories, blood banks, etc. In Iraq, the total number of health institutions in Baghdad city was 294 , the total number of government hospitals was reached 49 , while the total numbers of private hospitals were 37 and the total number of other health institutions reached was 208 as shown in figure 3.

The typical medical waste is sampled from three health institutions in Baghdad city to compare the results in this study. 


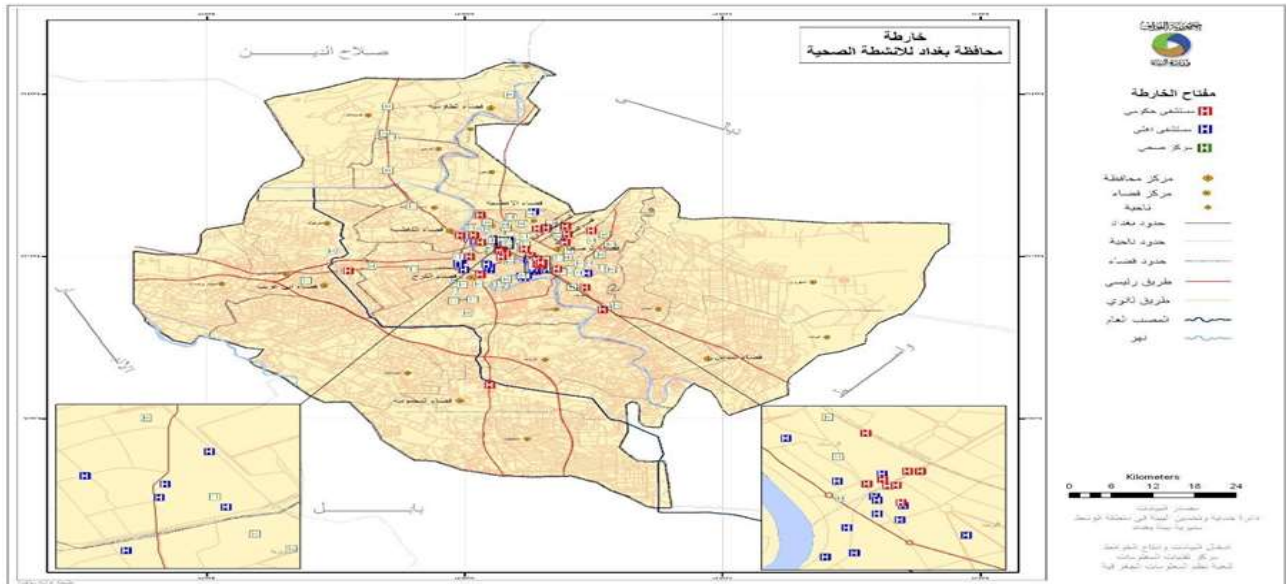

Fig. 3. The health institutions' sites, (government hospital - private hospital - health centre) in Baghdad [15]

The total and infectious healthcare waste generation rates by the number of hospital beds for a high-income country, as shown in the table 1 .

Table 1: The total and infectious healthcare waste generation rates by The number of hospital beds [14]

\begin{tabular}{|l|l|l|l|l|}
\hline United state & \multicolumn{3}{|l|}{ Total waste } & \multicolumn{2}{l|}{ Infectious waste } \\
\hline No. of hospital beds & $\mathrm{Kg} /$ bed a day & $\mathrm{Kg} /$ patent a day & \% of total waste & $\mathrm{Kg}$ /day(calculated) \\
\hline$<100$ & 2.59 & 5.13 & 13.3 & 0.34 \\
\hline $100-299$ & 4.70 & 7.16 & 15.0 & 0.70 \\
\hline $300-499$ & 5.67 & 8.63 & 14.9 & 0.84 \\
\hline$>500$ & 5.83 & 0.69 & 14.9 & 0.87 \\
\hline total & 4.18 & 6,93 & 15.0 & 0.63 \\
\hline
\end{tabular}

Baghdad produces approximate 1901.8 tons of medical waste per year. The government hospital produces 1614 ton/ year, the Private hospital produces 103.7 ton/year and the health centre produces 184.1 ton/year, as shown in figure 2. After the pandemic of COVID19 the medical waste has doubled in Baghdad city. For example, in December 2019 medical wastes were $82537 \mathrm{~kg}$, whereas in January 2021 the medical waste reached 174385 $\mathrm{kg}$.

weight (ton/year)

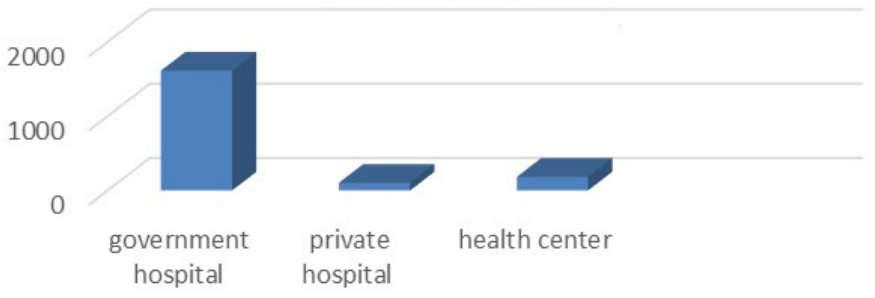

Fig. 4 The total weight of all medical waste (ton/year) 
This study is a comparison between three waste incineration operations in three types of hospitals in Baghdad and the resulting ash study:

- Medical City Complex.

- Al-Amal National Hospital.

- Al Shifa Corona Virus Hospital

\subsection{The work steps}

We weighed the required amount of $30 \mathrm{~kg}$ of medical waste, then loaded it in the incinerator and ran the incinerator for an hour to monitor the combustion temperature. On the second day (the hospital safety department instruction), we open the chambers to collect the ash sample.

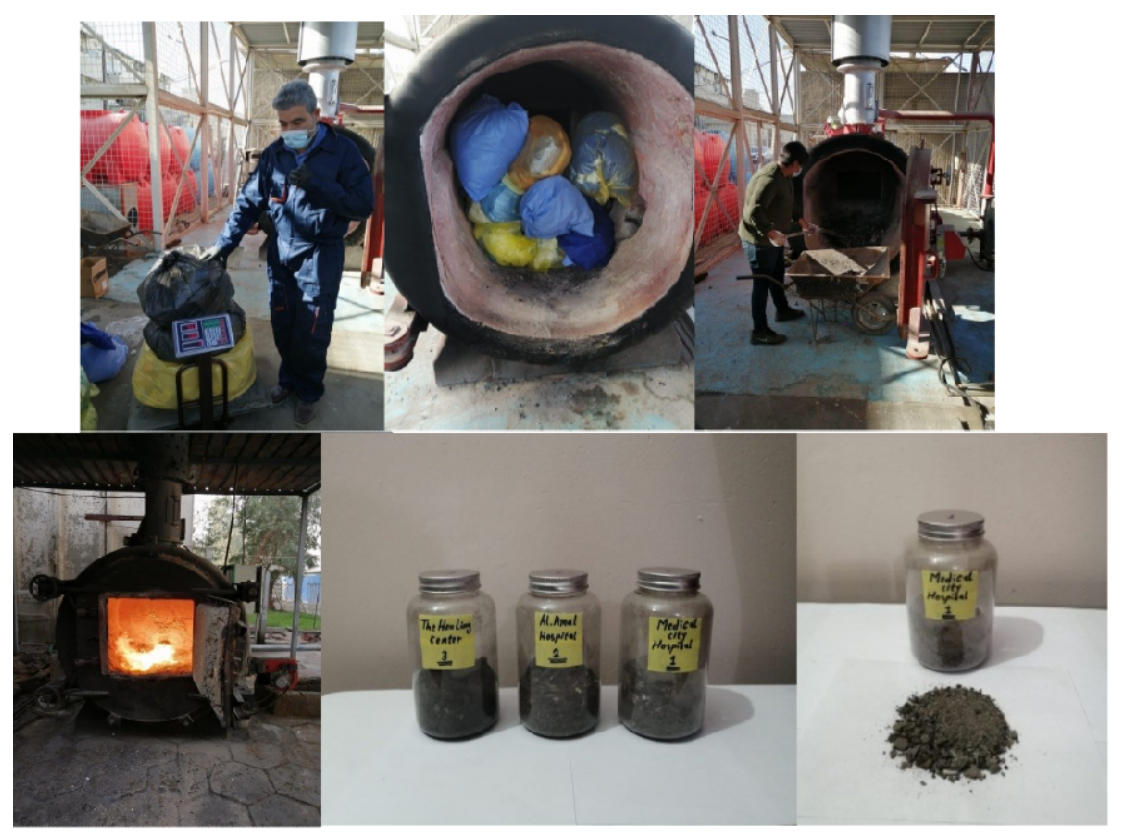

Fig. 5 Ash samples after incinerating medical waste

\subsection{Medical City Complex}

A medical city complex is a group of hospitals that contain 2715 beds. The medical waste production average per hospital is between $(0.5-1) \mathrm{kg}$ for each bed per day. The hospitals complex incinerator has two combustion chambers. Each of them has one diesel burner, which raises the temperature of the primary chamber to $400^{\circ} \mathrm{C}$, and the secondary chamber raises the temperature to $(600-700)^{\circ} \mathrm{C}$. The tested waste weight is $30 \mathrm{~kg}$, and after burning, the remaining ash is $9 \mathrm{~kg}$, whereas the sampled ash weight is only 6.7 grams. 


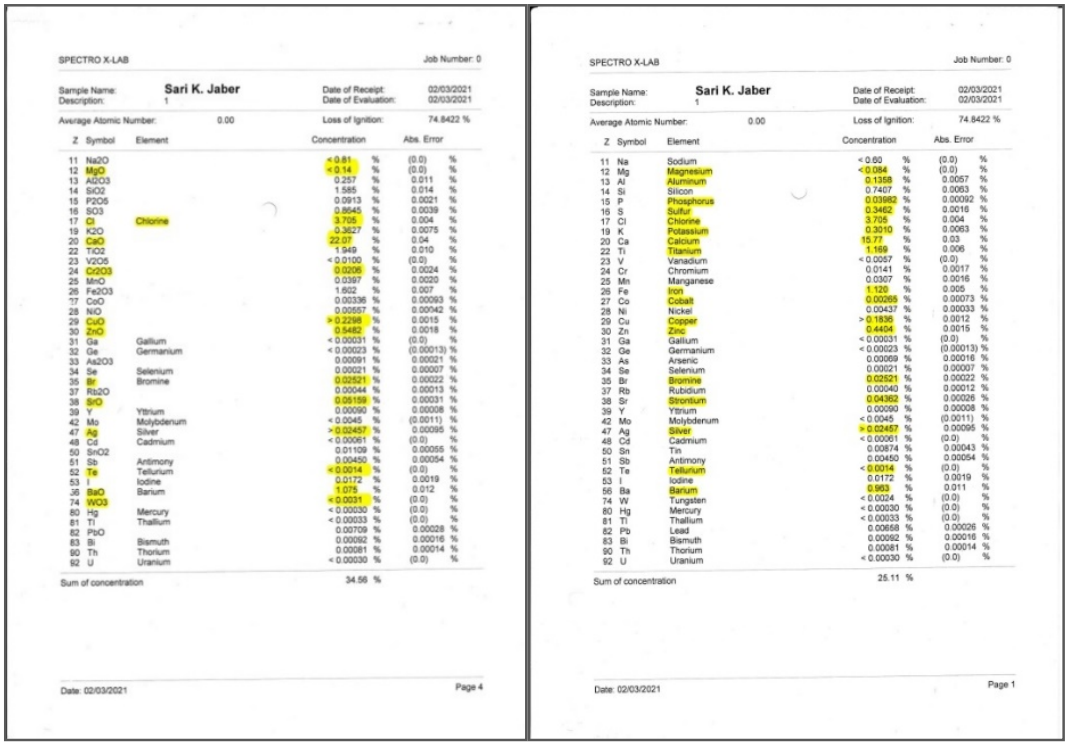

Fig. 6 The result of the laboratory test of the elements and oxides in Medical City Complex.

Note the element and oxides, yellow-marked are above the standard safe level for use in sanitary landfills.

Table 1. Concentrations of heavy elements present in the ash resulting from burning MW

\begin{tabular}{|c|c|c|c|}
\hline Heavy elements & PPM & $\begin{array}{c}\text { Permissible PPM Ministry of Environment in } \\
\text { Iraq }\end{array}$ & \\
\hline$(\mathrm{Pb})$ Lead & 65.8 & 530 & \\
\hline$(\mathrm{Fe})$ Iron & 11200 & 6000 & + \\
\hline$(\mathrm{Cu})$ Copper & 1836 & 190 & + \\
\hline$(\mathrm{Zn})$ Zinc & 4404 & 720 & + \\
\hline$(\mathrm{Cd})$ Cadmium & 6.1 & 12 & \\
\hline$(\mathrm{Cr})$ Chromium & 141 & 380 & \\
\hline
\end{tabular}

Table 4. Concentration of another elements present in ash resulting from burning MW

\begin{tabular}{|c|c|c|c|}
\hline Author's elements & PPM & Permissible PPM Ministry of Environment in Iraq & \\
\hline$(\mathrm{Ca})$ Calcium & 157700 & 12 & + \\
\hline$(\mathrm{Hg})$ Mercury & 245.7 & 10 & + \\
\hline$(\mathrm{Ni})$ Nickel & 43.7 & 210 & + \\
\hline$(\mathrm{Sb})$ Antimony & 45 & 15 & \\
\hline$(\mathrm{Se})$ Selenium & 2.1 & 100 & + \\
\hline$(\mathrm{Ag})$ Silver & 245.7 & 15 & \\
\hline$(\mathrm{Ti})$ Thallium & 3.3 & 15 & \\
\hline$(\mathrm{As})$ Arsenic & 6.9 & 55 & \\
\hline
\end{tabular}

\subsection{Al-Amal National Hospital.}

This hospital is specialized in cancer disease treatment and it contain 200 beds. Each bed produces between $(0.5-1) \mathrm{kg}$ of waste daily. The hospital incinerator contains two combustion chambers. The primary chamber has two diesel burners raise the temperature to $400^{\circ} \mathrm{C}$, and the secondary combustion chamber has one diesel burner that raises the 
temperature to $600^{\circ} \mathrm{C}$. The tested waste weight is $30 \mathrm{~kg}$ and the remaining ash after the burning is $15 \mathrm{~kg}$ whereas the sample ash weight is 5.25 grams.

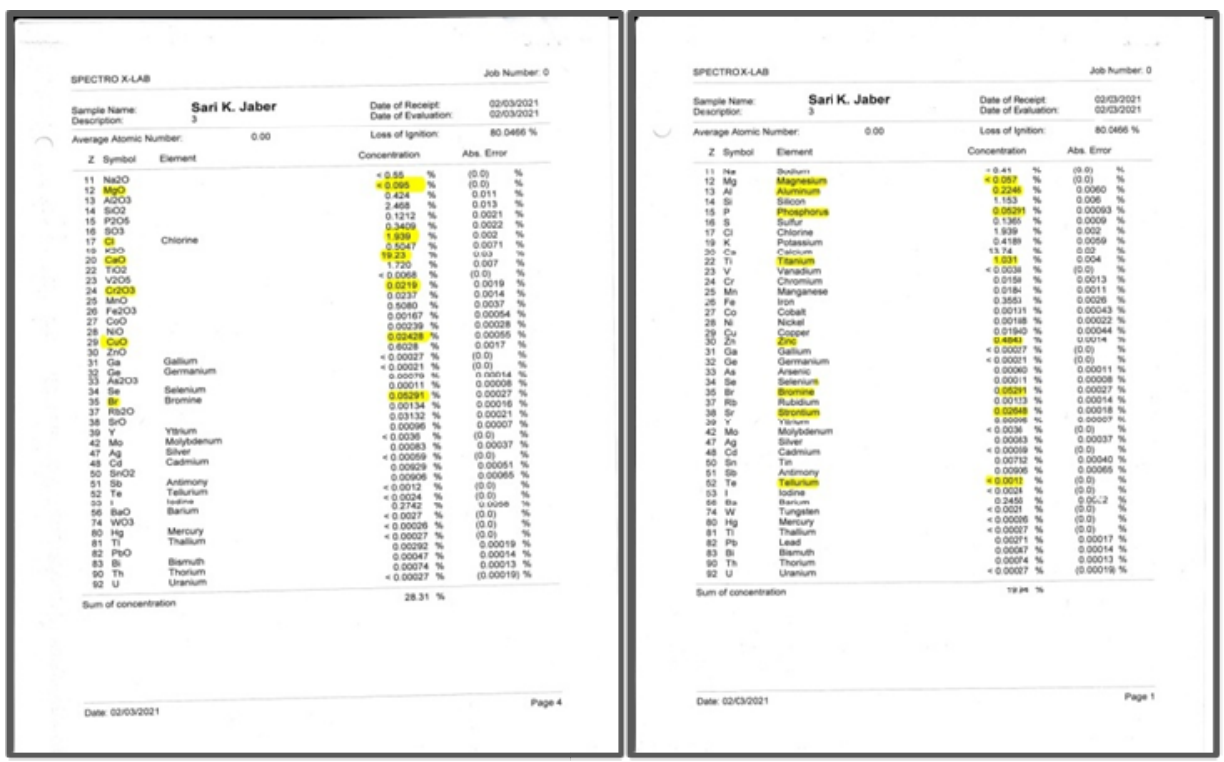

Fig. 8. The result of the laboratory examination of the elements and oxides in the Al-Amal National Hospital.

Note the element and oxides, yellow-marked are above the standard safe level for use in sanitary landfills

Table 5. Concentrations of heavy elements present in the Ash resulting from burning MW

\begin{tabular}{|c|c|c|c|}
\hline Heavy elements & PPM & Permissible PPM Ministry of Environment in Iraq & \\
\hline$(\mathrm{Pb})$ Lead & 27.1 & 530 & \\
\hline$(\mathrm{Fe})$ Iron & 3553 & 6000 & \\
\hline$(\mathrm{Cu})$ Copper & 194 & 190 & \\
\hline$(\mathrm{Zn})$ Zinc & 4843 & 720 & \\
\hline$(\mathrm{Cd})$ Cadmium & 5.9 & 12 & \\
\hline$(\mathrm{Cr})$ Chromium & 150 & 380 & \\
\hline
\end{tabular}

Table 6. Concentration of another elements present in ash resulting from burning MW

\begin{tabular}{|c|c|c|c|}
\hline Author's elements & PPM & Permissible PPM Ministry of Environment in Iraq & \\
\hline$(\mathrm{Ca})$ Calcium & 137400 & 12 & \\
\hline$(\mathrm{Hg})$ Mercury & 2.6 & 10 & \\
\hline$(\mathrm{Ni})$ Nickel & 18.8 & 210 & \\
\hline$(\mathrm{Sb})$ Antimony & 90.6 & 15 & \\
\hline$(\mathrm{Se})$ Selenium & 1.1 & 100 & \\
\hline$(\mathrm{Ag})$ Silver & 8.3 & 15 & \\
\hline$(\mathrm{Ti})$ Thallium & 2.7 & 15 & \\
\hline$(\mathrm{As})$ Arsenic & 6.0 & 55 & \\
\hline
\end{tabular}

\subsection{Al Shifa coronavirus Hospital}

This hospital is a healing center for the (COVID-19) patients, as it contains 250 beds and produces (5-6) $\mathrm{kg}$ of medical waste per bed /day. The hospital incinerator contains two 
combustion chambers. The primary chamber has a diesel burner that raises the temperature to $400^{\circ} \mathrm{C}$, and the secondary combustion chamber also has a diesel burner that raises the temperature from $400{ }^{\circ} \mathrm{C}$ to $800{ }^{\circ} \mathrm{C}$. The tested material weight is $30 \mathrm{~kg}$, and the remaining ash weight after burning is $11 \mathrm{~kg}$, whereas the sampled ash materials are 3.5 grams.

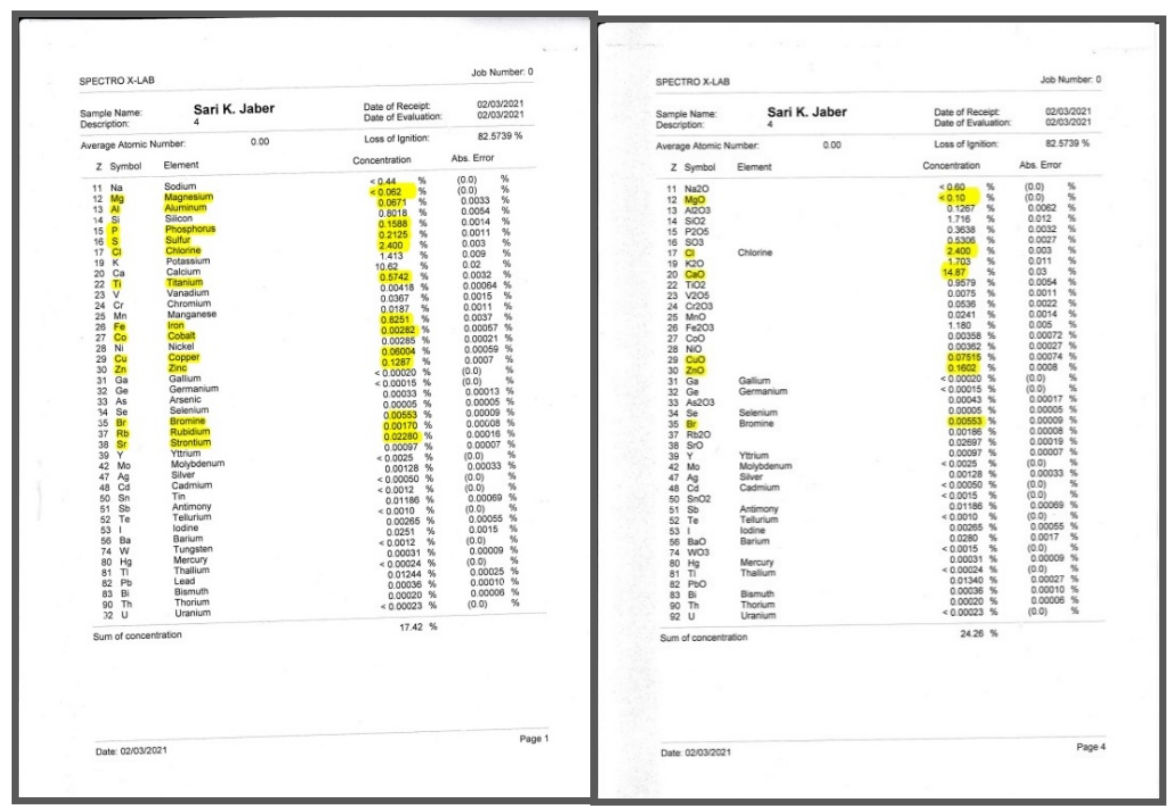

Fig.9. The result of the laboratory examination of the elements and oxides in the Al-Amal National Hospital.

Note the element and oxides, yellow-marked are above the standard safe level for use in sanitary landfills.

Table 7. Concentrations of heavy elements present in the ash resulting from burning MW

\begin{tabular}{|c|c|c|c|}
\hline Heavy elements & PPM & Permissible PPM Ministry of Environment in Iraq & \\
\hline$(\mathrm{Pb})$ Lead & 124.4 & 530 & \\
\hline$(\mathrm{Fe})$ Iron & 8251 & 6000 & \\
\hline$(\mathrm{Cu})$ Copper & 6004 & 190 & \\
\hline$(\mathrm{Zn})$ Zinc & 1287 & 720 & \\
\hline$(\mathrm{Cd})$ Cadmium & 5 & 12 & \\
\hline$(\mathrm{Cr})$ Chromium & 367 & 380 & \\
\hline
\end{tabular}

Table 8. Concentration of another elements present in ash resulting from burning MW

\begin{tabular}{|c|c|c|c|}
\hline Author's elements & PPM & Permissible PPM Ministry of Environment in Iraq & \\
\hline$(\mathrm{Ca})$ Calcium & 106200 & 12 & \\
\hline$(\mathrm{Hg})$ Mercury & 3.1 & 10 & \\
\hline$(\mathrm{Ni})$ Nickel & 28.5 & 210 & \\
\hline$(\mathrm{Sb})$ Antimony & 118.6 & 15 & \\
\hline$(\mathrm{Se})$ Selenium & 55.3 & 100 & \\
\hline$(\mathrm{Ag})$ Silver & 12.8 & 15 & \\
\hline$(\mathrm{Ti})$ Thallium & 2.4 & 15 & \\
\hline$(\mathrm{As})$ Arsenic & 1.5 & 55 & \\
\hline
\end{tabular}




\section{CONCLUSIONS}

We worked on burning medical waste according to its arrival from the hospital, and the experience was in each hospital and its incinerator separately. To analyses the ash, we found that the proportions of heavy minerals and amount of another materials is high. One of the main reasons is that the process of isolating waste before incineration, even if it is present, is imprecise and efficient. Then the ashes are thrown in the municipality dumps and not in certain areas for this purpose, which causes them to spread in the air. It causes serious diseases in the respiratory system. The penetration and oxidation of minerals into landfill soil is a major risk to the soil. It may also reach the groundwater. For this reason, it is necessary to define areas designated for burying medical waste that differ from those used for municipal waste. Or mixing heavy metals with bricks and cement is an excellent idea for fixing the heavy metals in the cement and are useful in construction operations.

\section{References}

1. L. WJ, Li J, Wu BL, Yi JQ Xie R, "Emissions investigation for a novel medical waste incinerator. J Hazard Mater.," J. H. M., vol. 166, no. 1, pp. 365-371, Jul (2009).

2. S. Papamarkou, P. Tsakiridis, G. Bartzas, K. Tsakalakis, C. Tsakalou, "Characterization and leachability evaluation of medical wastes incineration fly and bottom ashes and their vitrification outgrowths," J. Env. Che. Eng., vol. 6, no. 1, pp. 367-376, (2018).

3. E.Tınmaz Köse, A. Yıldız. A. Aky1ldız, "Compressive strength and heavy metal leaching of concrete containing medical waste incineration ash.," C. B. Mat., vol. 138, no. 1, pp. 326-332, (2017).

4. A.Ferraz, S. Afonso, M.M, "Incineration of different types of medical wastes: emission factors for gaseous emissions," At. Env., vol. 37, pp. 5415-5422, (2003).

5. A. Ferraz, B. Cardoso, S. Pontes M.M, "Concentration of Atmospheric Pollutants in the Gaseous Emissions of Medical Waste Incinerators," J. A. \& WMA., vol. 50, pp. 131-136, (2011).

6. WHO, "Guidelines for the safe disposal of unwanted pharmaceuticals in and after emergencies, Report No. WHO/EDM/PAR/99.2.," Geneva, WHO, (1999).

7. W.H.O, "Health care waste management rapid assessment tool (RAT), 2nd ed.," Geneva, (2010).

8. J.Han, B. Zhao, Y. Wang, W. Chen, F. Xing L. Qin, "Thermal degradation of medical plastic waste by in-situ FTIR, TG-MS and TG-GC/MS coupled analyses," J.A. and Ap. Pyr., vol. 136, pp. 132-145, (2018).

9. Qiushuang Li, Yuxi Ge, Chen Jiang, Zhiyuan Ren, Ren, "Use Incentive Approach to Promote BAT/BEP for Centralized Incineration Facilities of Medical Waste in China," Pro. Env. Sci., vol. 31, pp. 457-464, (2016).

10. T. Chen, J.Wu, J. Wu, J.Zhang, "TG-MS analysis and kinetic study for thermal decomposition of six representative components of municipal solid waste under steam atmosphere," J. Waste Manag., vol. 43, pp. 152-161, (2015).

11. N. Deng, Y. Zhang, Y. Wang, "Thermogravimetric analysis and kinetic study on pyrolysis of representative medical waste composition," J. Waste Manag., vol. 28, pp. 1572-1580, (2008).

12. M. Su-Ling, Brooks, E. Windfeld, "Medical waste management - A review," J. Env. Man., vol. 163, pp. 98-108, (2015). 
13. H. Liu,Guo-XiaWei Fang Liu, "Characteristics and Treatment Methods of Medical Waste Incinerator Fly Ash: A Review," Tianjin, September 26,vol.10, pp.173, (2018).

14. F.Zhang, Z. Hao, H.Wang. L. Zhao, "Levels of polycyclic aromatic hydrocarbons in different types of hospital waste incinerator ashes" Sc. Tot. Env., vol. 397, pp. 24-30, (2008).

15. Iraqi Ministry of Environment. Technical department. 